\title{
REGULAR ARTICLE \\ ECONOMIC OF GREEN HOUSE ROSE PRODUCTION IN KRISHNAGIRI DISTRICT, INDIA
}

\author{
M. NAVEEN KUMAR* ${ }^{*}$ S. RAVICHANDRAN
}

Department of Agricultural Economics, Annamalai University, Chidambaram 608 o02, Tamil Nadu, India

\begin{abstract}
Horticulture crops play a unique role in economy of a country and its farmers. The conventional open field crops production generates and unremunerated production and cause of biodiversity. In order to overcome the problem, protected cultivation technology (green house) is need of the hour. Protected cultivation technology can be an effective mechanism for conserving agro-biodiversity. Greenhouse rose cultivation, an investment intensive and which need specific knowledge, skill and thoroughness in production, increases the income level of the farmer. Hence an attempt was made to study the economics of greenhouse cultivation. Krishnagiri district is the major producer of flower crops in Tamil nadu. There are 10 blocks, they are arranged in descending order and top two blocks viz., Hosur and Thalli were selected. Greenhouse growers list of the selected blocks were prepared and 60 respondents were randomly selected from the list. The study found that the average greenhouse size was at 1.76unit. ( 1 unit $=1000$ sq. $\mathrm{m}$ ). It found that gross return from greenhouse unit per year was at Rs.10, 95000 and the net return was at Rs.6, 33,797.95. BCR was 1.46 at 15 per cent discount rate.
\end{abstract}

Keywords: Greenhouse, Protected cultivation, Flower crops Rose, Krishnagiri, Investment analysis

\section{INTRODUCTION}

Horticulture crops are important in determining the nation's economy, as their cultivation and trade are important pillars of farmer's income [1]. The major hindering factor for the cultivation of horticulture crops is, the high labor input needed in the establishment and maintenance. India has been equipped with extensive range of atmosphere and geographical conditions and in that capacity is most reasonable for developing different types of plants, for example, organic products, vegetables, flowers, nuts etc [2].

Floriculture is mainly referred as an art and at the same time a science of growing flowers [3]. In floriculture main aspects are propagation, cultivation, maintenance and harvesting of ornamentals. It details the different propagation scenarios from conventional to advanced technologies like tissue culture propagation of ornamentals [4].

According to the horticulture production year book reports, total horticultural crop area of 23694 (ooo ha) with a production of 268848 (oooMT), and area under flower crops are 232.7 (ooo ha) with production of 76731.9 (ooo MT) [5].

The general aim of the present study is economics of greenhouse rose production and the specific objectives are i) To study the socio economic level of greenhouse rose cultivating farmers in the study area, ii) To assess the production costs and return of greenhouse rose cultivation in the study area. The stated objectives would have required verification of the following hypothesis: a) Greenhouse rose cultivation made a positive impact on farmer's income, b) Greenhouse rose cultivation made a positive impact on yield of rose.

\section{Methodology}

The study was taken up in Hosur Taluk of Krishnagiri district, Tamilnadu, there are five taluks namely, Krishnagiri, Uthangarai, Pochampalli, Hosur and Denkanikottai, among them Hosur Taluk and Denkanikottai placed first and second in cut flower production because of its congenial climate for cut flower production. Multi stage random sampling technique was adopted to select 60 sample respondents, as district at first stage, taluk in second stage and block in third stage. In the last stage greenhouse rose growers list were prepared for the top two blocks and the sample of 60 was randomly selected and equally distributed to the selected blocks (Hosur and Thalli blocks). The relevant primary data are collected from the sample respondents using interview schedule the collected data are classified and tabulated with the help of computer programming.

\section{Received 10 November 2017; Accepted 30 December 2017 \\ *Corresponding Author}

\section{Naveen Kumar}

Department of Agricultural Economics, Annamalai University, Chidambaram 608 002, Tamil Nadu, India

Email: naveen13091991@gmail.com

( This article is open access and licensed under the terms of the Creative Commons Attribution License (http://creativecommons.org/licenses/by/4.o/) which permits unrestricted, use, distribution and reproduction in any medium, or format for any purpose, even commercially provided the work is properly cited. Attribution - You must give appropriate credit, provide a link to the license, and indicate if changes were made. 


\section{Tools of analysis}

The following statistical tools were employed for the analysis and the interpretation of the data. Percentage analysis was used for making simple comparisons. For calculating percentage, the frequency of the particular cell was multiplied by 100 and divided by the total number of respondents pertaining to particular cell. Percentage was corrected to two decimal places.

\section{I) Cost of cultivation of rose}

The cost of cultivation/production was estimated by adopting cost concepts like Cost A, Cost B and Cost C as defined by Directorate of Economics and Statistics, Government of India. (2000)

\section{Cost A: cost A includes i to viii}

\section{Cost of rose cuttings}

The duration of green house is estimated as five years of life hence 20 percent of rose cutting cost is taken as cost of cuttings

\section{Hired human labour Cost}

Human labour cost was one of the important constituents of the direct costs in rose production. It was evaluated from the actual wages paid by the farmer. Human labour was measured in man days.

\section{Value Machine Power}

Machine power was charged at the prevailing rates in the respective villages.

\section{Cost of Manures, fertilizers and plant protection chemicals}

Cost of manure was calculated based on the prevailing market rate in the area. Chemical fertilizers and plant protection chemicals were valued at the actual payment made by the farmer.

\section{Cost of Irrigation}

Irrigation cost includes labour cost for irrigating the field at the prevailing market wage rate and the electricity charges paid by the sample farmers.

\section{Depreciation}

Depreciation was worked out by straight-line method, at the rate of five per cent for farm buildings, ten per cent for farm equipment's and implements and fifty per cent for dead stocks.

\section{Taxes or land revenue}

The land revenue paid was reckoned at the actual payments made in the study area.

\section{Interest on working capital ( $i-v)$}

The paid out cost constituted the working capital. Normally, in farming, the inputs are not used at a time but at different points of time according to the requirements of the crop.

Cost $\mathrm{B}=$ Cost A1 plus Interest on fixed capital and rental value owned land

\section{Cost $\mathrm{C}=$ Cost $\mathrm{B}$ plus value of family labour}

\section{II) Cost of Production}

Cost of production is per unit cost (per bunch of rose) to produce one bunch of rose, which is derived by using the below formula:

$$
\text { Cost of production } / \text { bunch }=\frac{\text { CostC }}{\text { No.of Bunches produced }}
$$

\section{III) Returns}

Gross income was calculated based on monthly average production and average price of cut flower selling. Net income was derived by subtracting the total cost incurred in production from the gross income.

\section{IV) Investment analysis}

Cut flower has cultivated in green house and has a gestation period of six months and considerable investments are made before the crop begins to yield. The returns are spread over a period. The worthiness of investments on Annual crops in which cost and benefits are distributed over years has to be evaluated by taking into consideration the life period of the crop. In the present study, the productivity of capital was measured using discounted measures such as net present value and benefit-cost ratio. They are discussed below.

a) Net Present Value (NPV) and b) Benefit-Cost Ratio (B-C Ratio) were calculated as explained previously [6]

\section{RESULTS AND DISCUSSION}

\section{Socio economic status of the sample respondents}

The socio economic status was analysed the sample farmer's family particulars, age, education, farm income and experience are presented in table 1.

Table 1 represent the demographic status viz., family composition, age, education and experience in rose cultivation. It revealed that the average family size was 5.11. It consists of 2.25 male (43.97 per cent), 1.73 (33.88 per cent) of female and 1.13 (22.15 per cent) of children. It could be inferred that; the sample households were male dominant in size. The age group showed that above $50 \mathrm{y}$ were consisting 25 per cent. The farmers in the age group of 36-50 y constituted highest 63.33 per cent. The farmers in the age group of below $35 \mathrm{y}$ constituted 11.67 per cent. It also inferred that the 96.7 per cent of the sample respondents were literates but nearly 15 per cent of the sample respondent's literacy levels were at primary level and 47 per cent of the sample respondents were studied at secondary level. 18per cent of the sample respondent's literacy level were higher secondary level. It showed that Majority of the respondents have adequate level of education. Farmers having experience in green house rose cultivation for a period of 3-5 y constituted 82 per cent of the sample respondents. It inferred that majority of the farmers were more experienced in rose cultivation.

\section{Farm holdings of sample respondents}

The farm holdings of the sample respondent were analyzed and results are furnished in table 2. 
Table 1: Demographic particulars of sample respondents

\begin{tabular}{|c|c|c|c|}
\hline S. No. & Particulars & Number of respondent & Per cent \\
\hline \multicolumn{4}{|c|}{ a)Family composition } \\
\hline 1 & Male & 135 & 43.97 \\
\hline 2 & Female & 104 & 33.88 \\
\hline \multirow[t]{2}{*}{3} & Children & 67 & 22.15 \\
\hline & Total & 306 & 100 \\
\hline \multicolumn{3}{|c|}{$\begin{array}{l}\text { Average family size } \\
\text { b) Age group of sample size }\end{array}$} & 5.11 \\
\hline 1. & $<35$ & 7 & 11.67 \\
\hline 2 & $36-50$ & 38 & 63.33 \\
\hline 3 & $\begin{array}{l}>50 \\
\text { All age groun }\end{array}$ & $\begin{array}{l}15 \\
60\end{array}$ & $\begin{array}{l}25 \\
100\end{array}$ \\
\hline \multicolumn{4}{|c|}{ c)Educational Status } \\
\hline 1 & Illiterate & 2 & $3 \cdot 3$ \\
\hline 2 & Primary & 9 & 15 \\
\hline 3 & Secondary & 28 & 47 \\
\hline 4 & Higher Secondary & 11 & 18 \\
\hline \multirow[t]{2}{*}{5} & Collegiate & 10 & 16.7 \\
\hline & Total & 60 & 100 \\
\hline \multicolumn{4}{|c|}{ d)Experience in Green house rose cultivation (in years) } \\
\hline 1 & $2 \mathrm{y}$ & 4 & 6 \\
\hline 2 & $3-5 y$ & 49 & 82 \\
\hline 3 & $>5 \mathrm{y}$ & 7 & 12 \\
\hline & Total & 60 & 100 \\
\hline
\end{tabular}

Table 2: Farm Holdings of the sample respondents (in ac)

\begin{tabular}{llll}
\hline S. No. & Type of land & Area (in ac) & Per cent \\
\hline 1 & Wet land & 2.62 & 43.43 \\
2 & Garden Land & 3.28 & 54.36 \\
3 & Dry Land & 0.13 & 2.21 \\
& Total area & 6.03 & 100.00 \\
\hline
\end{tabular}

Table 3: Distribution of greenhouse among sample respondents

\begin{tabular}{llll}
\hline S. No. & No. of units & Number of farmers & Per cent \\
\hline 1 & 1 & 30 & 50.00 \\
2 & 2 & 18 & 30.00 \\
3 & 3 & 8 & 13.33 \\
4 & 4 & 4 & 6.67 \\
& Total & 60 & 100.00 \\
& Average size & & 1.76 \\
\hline
\end{tabular}

*One unit equals to 1000 square meters

It could be seen from the table that the garden land constituted the highest per cent of the average farm holding with $3.28 \mathrm{ac}$, and wet land constituted 43.43 per cent with a average of 2.62. It could be inferred that, the garden land were dominant in per cent compare to wet land and dry land.

\section{Distribution of greenhouse among sample respondents}

The number of greenhouse hold by the sample respondents were analyzed and results are presented in table 3

The above table revealed that the average greenhouse size was 1.76 unit. It was also found that farmers one unit of greenhouse constituted 50 per cent of the sample respondents. The farmers having two units and three units constituted 30 per cent and 13.37 per cent respectively. And the farmers having four units of greenhouse constituted 6.67 per cent. It is inferred that the increased number of units hold by the farmers might witnessed the viability of greenhouse rose cultivation. The size of one unit is 1000 sq. $\mathrm{m}$.

\section{Cost of production of greenhouse rose cultivation}

The greenhouse technology involves intensive investment. The data on establishment of greenhouse and installation of drip irrigation system required technical advice and reputed institution. The collected information on establishment cost is presented in table 4. 
Table 4: Establishment cost of greenhouse and drip irrigation per unit (1000 sq. m)

\begin{tabular}{llll}
\hline S. No. & Particulars & Amount(Rs) & percentage \\
\hline Cost of green house & & 54.21 \\
1 & Cost of Pipe/4 ton & 607806.00 & 0.74 \\
2 & Cost of gutter sheet/100 kg & 8300.00 & 18.10 \\
3 & Cost of foundation pipe & 203004.00 & 8.99 \\
4 & Cost of clothing material & 100900.00 & 82.05 \\
& Total (I) & 920010.00 & 8.14 \\
1 & & & 9.21 \\
2 & Cost of Drip in line & 91340.00 & 0.27 \\
3 & Cost of Misting & 103341.00 & 0.34 \\
& Cost of Service line & 3035.00 & 17.94 \\
& Cost of Misting 1 & 3447.00 & 100.00 \\
\hline
\end{tabular}

It could be seen from table 16 that the total cost involved in establishing a greenhouse unit was estimated at Rs.11,21,173.00, of this greenhouse construction constituted Rs.920010.00 (82.05 per cent) and drip irrigation constituted 201163.00 (17.94 per cent).

Table 5: Cost of cultivation of greenhouse rose (1000sq. $\mathrm{m})$

\begin{tabular}{llll}
\hline S. No. & Particulars & Cost (Rs) & Per cent \\
\hline 1 & Cost of cutting(20\% cost)* & 21246.67 & 4.61 \\
2 & Labour wages & 136279.30 & 29.54 \\
3 & Plant production chemicals & 4670.00 & 1.01 \\
4 & Fertilzer & 10530.00 & 2.28 \\
5 & Farm yard manure & 11830.00 & 2.57 \\
6 & Land preparation & 1500.00 & 0.33 \\
7 & Depreciation on green house (12.5\%) of green house establishment cost & 115001.30 & 24.94 \\
8 & Value of insurance & 3000.00 & 0.65 \\
9 & Cost A (1-8) & 304057.27 & 65.93 \\
10 & Rental value of land & 96000.00 & 20.82 \\
11 & Interest on fixed capital@11.50\% (green house+Drip) & 25145.38 & 5.45 \\
12 & Cost B (9-11) & 425202.65 & 92.19 \\
13 & Family labour wages & 36000.00 & 7.80 \\
14 & Cost C (12and13) & 461202.65 & 100.00 \\
\hline
\end{tabular}

*cost of cutting apportioned for $5 \mathrm{y}$.

\section{Economics of greenhouse rose production in krishnagiri district}

The cost of cultivation and returns were calculated for the growers who are availing subsidy and the growers who are cultivating rose without subsidy separately. The cost of investment for the greenhouse the Cost of cultivation and returns of greenhouse rose cultivation is presented in table 5 .

It was observed from the table that among the components of cost of cultivation labour wages occupied a major share (29.54 per cent) followed by depreciation of green house (24.94 per cent) and rental value of land (20.82 per cent). These three components put together constituted (75 per cent) of the cost of cultivation of greenhouse rose.
And family labour charge contribution also showed a significant (7.81 per cent). It also observed that the cumulative of cost A (operational expenses) constituted (65.93 per cent) and cost B as (92.19 per cent).

Cost of production and Returns of greenhouse rose cultivation

The average rose production in one greenhouse unit per year was arrived at 21,900 bunches and the cost of production analysis showed that the average cost of production per bunch was Rs.21.06 and net return per bunch was calculated as Rs.28.94 per bunch.

Returns Based on cost of cultivation gross and net returns were calculated and it is given in table 6

Table 6: Return per unit of greenhouse

\begin{tabular}{lll}
\hline S. No. & Particulars & Amount (Rs) \\
\hline 1 & Total flower production/yr/unit & 21900 bunches/yr \\
2 & Sale price for flowers/Bunch & Rs 50/bunch \\
3 & Total return & 1095000.00 \\
4 & Net return & 633797.35 \\
\hline
\end{tabular}


The return analysis observed that from one unit of greenhouse produced 21,900 bunches per year. The sale proceeds were Rs.1095000 per year and net return as Rs.633797.35. In previous studies economic analysis of production and marketing of selected cut flowers grown under small sized Green house in Pune District [7, 8], Himachal Pradesh [9, 10], Haryana [11] were discussed. Jitendra [12] studied the comparative economic analysis of high tech and field rose cultivation around Bangalore city.

\section{CONCLUSION}

The cost and return analysis found that greenhouse rose cultivation is more efficient and remunerative and investment analysis found that it is a viable project for the farmers, as per agreement with the previous work [13]. This study also found that huge investment, lack of skilled labour, lack of cold storage facilities were the major problem for the greenhouse rose cultivation.

\section{REFERENCES}

1. Tilman D, Cassman KG, Matson PA, Naylor R, Polasky S. Agricultural sustainability and intensive production practices. Nature. 2002 Aug 8;418(6898):671.

2. Girard P, Fallot A. Review of existing and emerging technologies for the production of biofuels in developing countries. Energy for sustainable development. 2006;10:92-108.

3. Halevy AH. Handbook of flowering. CRC Press; 1989 Aug 31.

4. Bonato Negrelle RR, Mitchell D, Anacleto A. Bromeliad ornamental species: conservation issues and challenges related to commercialization. Acta Scientiarum. Biological Sciences. 2012;34.

5. Sudhagar. S. Productive and marketing of cut flower (Rose and Gerbera) in Hosur Taluk. International
Journal of Business and Management Invention 5: 1525. 2013.

6. Karthick V, Mani K, Anbarassan A. Mango pulp processing industry in Tamil Nadu-an economic analysis. American International Journal of Research in Humanities, Arts and Social Sciences. 2013 Mar; 2:48-52.

7. Bhegade S. Economic analysis of production and marketing of selected cut flowers grown under small sized Green house in Pune District. Thesis submitted to Mahatma Phule Krishi Vidyapeeth, Rahuri, Maharashtra. 2002.

8. Jagtap P. V.34. Production and marketing management of hi-tech floriculture „A case study of Chintamani Floriculture Project in Pune district. Thesis submitted to Mahatma Phule Krishi Vidyapeeth, Rahuri, Maharashtra. 2008

9. Bhoopesh Punera. Economics and Institutional Aspects of Protected Cultivation of Carnation in Himachal Pradesh. Agricultural Economics Research Review 30:73-80. 2017.

10. Choudhary. Anil K. Scaling up of protected cultivation in Himachal Pradesh, India. Current Science, 111 :272277. 2016

11. Goyal, S. K. Economics of Rose cultivation and its Marketing in Sonepat District of Haryana State", Indian Journal of Agriculture Marketing, 13:44-51. 1999.

12. Jitendra B. K. Comparative study of High Tech and Field Rose Cultivation around Bangalore City. Thesis submitted to Mahatma Phule Krishi Vidyapeeth, Rahuri, Maharashtra. 2007.

13. Mathivanan. B. A study on rose cultivation and marketing pattern in Hosur Taluk. Journal of Exclusive Management Science 2:10-14. 2013. 